\title{
Translation to Brazilian Portuguese and Cultural Adaptation of the Craniocervical Dysfunction Index
}

\author{
Ana Carolina Marcotti Dias ${ }^{1}$ Marcelo Yugi Doi ${ }^{2}$ Arthur Eumann Mesas ${ }^{3}$ \\ Michelle Moreira Abujamra Fillis ${ }^{3}$ Fatima Cristina Alves Branco-Barreiro ${ }^{4}$ \\ Luciana Lozza de Moraes Marchiori ${ }^{5}$
}

${ }^{1}$ Department of Rehabilitation Sciences, Universidade Norte do Paraná (Unopar), Londrina, PR, Brazil

2 Department of Health Sciences, Universidade Norte do Paraná (Unopar), Londrina, PR, Brazil

3 Department of Public Health, Centro de Ciências da Saúde, Universidade Estadual de Londrina, Londrina, PR, Brazil

${ }^{4}$ Department of Neuroscience, Instituto de Psicologia, Universidade de São Paulo (USP), São Paulo, SP, Brazil

${ }^{5}$ Department of Speech Therapy, Universidade Norte do Paraná (Unopar), Londrina, PR, Brazil

Address for correspondence Ana Carolina Marcotti Dias, Universidade Norte do Paraná Ringgold standard institution Departamento de Ciências da Reabilitação, Rua Marselha 183, Jardim Piza, Londrina, 86041-120, Brazil (e-mail: acmarcotti@hotmail.com).

Int Arch Otorhinolaryngol 2018;22:291-296.

\begin{abstract}
Introduction Functional disorders of the craniocervical region affect $77.78 \%$ of Brazilian teachers. Among the most common instruments used to assess craniocervical disorders in a detailed and objective way, none had been translated to Brazilian Portuguese and adapted to Brazilian culture.

Objectives To translate to Brazilian Portuguese and to culturally adapt the Craniocervical Dysfunction Index (CDI).

Method The first phase of the study consisted of the translation, synthesis, backtranslation, and review of the contents by a committee of experts, who developed a trial version and sent all the steps to the original author. The trial version was applied to 50 teachers of an institution. The reliability and internal consistency were evaluated by Cronbach $\alpha$. For the validation, the Brazilian Portuguese version of the CDI was correlated with the Visual Analogue Scale (VAS) domains for cervicalgia and evaluated by Spearman $\rho$. Result Some expressions were adapted to the Brazilian culture. Among the participants who did not report neck pain in the VAS, $84.21 \%$ suffered from craniocervical dysfunction acording to the CDI. Among the participants who reported neck pain in the VAS, $100 \%$ suffered from craniocervical dysfunction according to the CDI. The CDI showed good internal consistency and satisfactory reliability measured by Cronbrach $\alpha(\alpha=0.717)$. There was a strong correlation between the CDI and the VAS score $(\rho=0.735)$.

Keywords

- neck pain

- questionnaires

- school teachers

Conclusion No difficulties were encountered in the translation and back-translation of the $\mathrm{CDI}$, and no problems were observed regarding the trial version developed; therefore, the Brazilian Portuguese version of the CDI is a valid and reliable instrument to evaluate the functional alteration of the craniocervical region.
\end{abstract}

received

September 10, 2017

accepted

December 9, 2017

published online

January 18, 2018
DOI https://doi.org/

10.1055/s-0037-1621743. ISSN 1809-9777.
Copyright $(2018$ by Thieme Revinter

Publicações Ltda, Rio de Janeiro, Brazil
License terms

(ㄷ) (i) $\ominus$ (\$) 


\section{Introduction}

Cervical spine disorders are among the most common ${ }^{1}$ musculoskeletal disorders, with a prevalence of $10 \%$ to $15 \%$, affecting $50 \%$ of the adult population at some point in life. ${ }^{2,3}$

Cervical dysfunction has several symptoms, such as limited range of motion, feeling of increased muscle tension, neck pain, headache, brachialgia, dizziness, and changes in voice and breathing patterns., ${ }^{4,5}$ Neck pain may be due to trauma, inadequate posture and repetitive strain in the workplace, which may cause microtraumas to the cervical vertebrae and periarticular soft tissues. ${ }^{6}$

The craniocervical region has an anatomical and functional relationship with the mandibular system. The rate of individuals with temporomandibular dysfunction who present signs and symptoms of craniocervical dysfunction (CCD) is high, and the relationship between the signs and symptoms of temporomandibular disorder (TMD) and craniocervical dysfunction (CCD seems to be related to the common innervation of the trigeminal-cervical complex, hyperalgesia individuals with TMD and the anteriorized neck posture due to an overload of the posterior muscles in an attempt to maintain the balance of the head in the spine. ${ }^{7,8}$

The imbalance between the cervical structures in the vertebrae, muscles and ligaments promotes commitment efficiency, resulting in pain (at rest or in motion) and hyperactivity of the muscles around the region, which limit the range of motion and postural changes. ${ }^{9}$ Cervical dysfunction may promote joint noises, important craniocervical postural changes, pain upon palpation of the cervical muscles, reduced range of motion, and even difficulty opening the mouth when there is an increased cervical lordosis. ${ }^{7}$

Studies have shown that impairments of the sensorimotor control in people with neck pain are manifested through changes in cervical kinesthesis, with difficulty in recognizing the position of the head, eye movement and balance; therefore, those affected tend to assume a compensatory body posture. ${ }^{4}$

Neck pain can have a major impact on people's lives. In order to measure the impact and limitations caused by this dysfunction, various questionnaires and rating scales have been developed. The most commonly used instruments are the Neck Disability Index (NDI), the Neck Pain and Disability Scale (NPDS), the Cervical Spine Outcomes Questionnaire (CSOQ), and the Northwick Park Neck Pain Questionnaire (NPNPQ). Although there are several and different questionnaires or indexes for the evaluation of cervical pain, including some of that have already been translated into Portuguese, such as the NDI and NPDS, these instruments only make the assessment in a subjective manner. ${ }^{10-12}$

The assessment of craniocervical dysfunction is performed objectively and comprehensively through the Craniocervical Dysfunction Index (CDI), which was developed based on the Helkimo Dysfunction Index. The CDI numerically grades the severity of the functional disorders of the cervical spine. ${ }^{13}$

Through this index it is possible to assess the craniocervical dysfunction, regardless of the opinion of the patients, of the severity of the symptoms, and of the need for treatment. The CDI objectively indicates the dysfunction of the cervical region by numerical average, assessing the degree of dysfunction and enabling the differential diagnosis, suggesting the priority and monitoring of the treatment these changes may be reassessed over time. ${ }^{13}$

Teachers, because of their professional activities, are likely to develop such disorders. A recent study in the city of Hong Kong, China, evidenced that $68.9 \%$ of teachers have neck pain. ${ }^{14}$ In Brazil, musculoskeletal pain of the cervical spine affects $77.78 \%$ of teachers due to their high workload and to the fact that they tend to spend large periods of time with their arms positioned at angles close to $90^{\circ}$, which causes compression of the soft tissue and impairs blood circulation. ${ }^{15}$

Considering the high rate of teachers with neck pain, it is important to check the craniocervical dysfunctions among this population, given the importance of physical health in the social environment. The translation, adaptation and validation of the CDI is a major step forward in the diagnosis, prevention and monitoring of such disorders among the Brazilian population. The CDI is an easy-access tool that provides objective results through numerical scores, which justifies the choice to translate and culturally adapt this index to the Brazilian population, and this was the objective of the present study.

\section{Method}

A cross-sectional study with translation and cross-cultural adaptation for the evaluation of CDI.

\section{Participants}

The sample was composed of 50 teachers from public schools in the city of Londrina, Brazil, and it is part of a larger research project known as Pro-Master. This wide research project has as target population: the public school teachers working in the city of Londrina, Brazil, and it aims to analyze the relationships connecting the health status relationships and lifestyle with the work of this population. The participants allocated to this part of the study were aged between 18 and 60 years. The exclusion criteria were people over 60 years of age and those with impairments in cervical mobility that affected the postural assessment; 9 patients were excluded due to age. Those who agreed to participate in the study signed a free and informed consent form.

The present research was approved by the Research Ethics Committee of our of Universidade Norte do Paraná under protocol number 45285015100000108 .

\section{Procedures}

The translation and cultural adaptation of the CDI, an index originally developed by Wallace and Klineberg, ${ }^{13}$ followed the steps outlined by Beaton et $\mathrm{al}^{15}{ }^{15}$ which include the translation from English into Portuguese, the retranslation into English, the analysis by acommittee of experts, and the development of the final version of the index. All of these stages were documented in writting.

At first, we contacted the authors of the CDI, who authorized the present study by e-mail. Subsequently, the process of translation and cultural adaptation was performed. 
Table 1 Modifications made in the translation

\begin{tabular}{|l|l|l|}
\hline $\begin{array}{l}\text { Modified } \\
\text { term }\end{array}$ & T1 and T2 & Version T-12 \\
\hline Impaired & $\begin{array}{l}\text { T1-Comprometimento } \\
\text { T2-Dificuldade }\end{array}$ & Comprometimento \\
\hline $\begin{array}{l}\text { Range of } \\
\text { movement }\end{array}$ & $\begin{array}{l}\text { T1-Amplitude } \\
\text { de movimento } \\
\text { T2-Movimento }\end{array}$ & $\begin{array}{l}\text { Amplitude de } \\
\text { movimento }\end{array}$ \\
\hline $\begin{array}{l}\text { Impaired } \\
\text { movement }\end{array}$ & $\begin{array}{l}\text { T1-Movimento } \\
\text { prejudicado } \\
\text { T2-Dificuldade } \\
\text { de movimento }\end{array}$ & $\begin{array}{l}\text { Movimento } \\
\text { prejudicado }\end{array}$ \\
\hline
\end{tabular}

Abbreviations: T1, Portuguese version made by the first translator; T2, Portuguese version made by the second translator; T-12, combined version of the two translations.

The translation of the CDI was made by two independent translators who were fluent in English, but who were Brazilian Portuguese native speakers. One of the translators had a background in physiotherapy, was a specialist in the field, and knew the studied index; the other translator lay the rated instrument and training in letters. Both translations of the index, called T1 and T2, were evaluated, and the discrepancies between them were discussed, as well as the discrepancies between the translations and the original instrument; the final instrument, a synthesis of the two transalations into Brazilian Portuguese, was called T-12 by the researchers (-Table 1 ).

The T-12 was submitted to two back-translations from Brazilian Portuguese into English by two different translators whon were native English speakers fluent in Brazilian Portuguese. None of the translators had any background in health care; one was an English teacher, and the other one worked in business administration. The back-translations were called RT1 and RT2 by the researchers.

After the back-translations were finished, a committee of experts composed of four physiotherapists, a speech therapist, two English teachers and a person working in business administration was formed. This committee evaluated all versions of the index (the original, T1, T2, T-12, RT1 and RT2) and developed the pre-final version of the Brazilian CDI. Then, the committee evaluated the semantic, idiomatic, cultural and conceptual aspects of the pre-final version, and developed the final Brazilian Portuguese version (T-12) and the final English back-translation (RT-12, - Appendix) of the index.

The pre-final version was submitted to a test to evaluate the understanding of the index during its application. A total of 50 subjects were selected among the teachers participating in the research project Pro-Master to take the pre-final version, and they were sent to an integrated speech therapy clinic.

During the test there were no complaints or concerns regarding the understanding of the questions and of the assessments performed. In this way it was observed the agreement semantics between the two translations. The index was applied in item "A" using fleximetry based on cervical mobility index, described by Wallace and Klineberg, inspection during movement of the cervical spine evaluated the item "B" for the presence or absence of joint sounds, the
Table 2 Brazilian version in English of the craniocervical dysfunction index

\begin{tabular}{|c|c|}
\hline Criteria & Scale \\
\hline \multicolumn{2}{|c|}{ a) Impairment of range of motion/mobility index } \\
\hline Normal range of motion & 0 \\
\hline Mildly-impaired range of motion & 1 \\
\hline Severely-impaired range of motion & 5 \\
\hline \multicolumn{2}{|c|}{ b) Functional impairment in the cervical joint } \\
\hline $\begin{array}{l}\text { Smooth movement without sounds } \\
\text { or pain in the cervical articulation }\end{array}$ & 0 \\
\hline $\begin{array}{l}\text { Sounds the in cervical joint - clicks, } \\
\text { snaps or similar sounds with } \\
\text { head movement }\end{array}$ & 1 \\
\hline $\begin{array}{l}\text { Lock - head or neck, momentarily } \\
\text { fixed }\end{array}$ & 5 \\
\hline \multicolumn{2}{|l|}{ c) Muscle pain } \\
\hline $\begin{array}{l}\text { Tenderness no pain upon palpation } \\
\text { of the cervical muscles }\end{array}$ & 0 \\
\hline $\begin{array}{l}\text { Tenderness pain in } 1 \text { to } 3 \text { palpated } \\
\text { places }\end{array}$ & 1 \\
\hline $\begin{array}{l}\text { Tenderness pain in } 4 \text { or more } \\
\text { palpated places }\end{array}$ & 5 \\
\hline \multicolumn{2}{|l|}{ d) Pain during cervical motion } \\
\hline No pain during motion & 0 \\
\hline Pain during one motion & 1 \\
\hline Pain during two or more motions & 5 \\
\hline \multicolumn{2}{|l|}{ e) Craniocervical posture } \\
\hline$>6 \pm 0.5 \mathrm{~cm}$ & 0 \\
\hline $4.5 \pm 0.5 \mathrm{~cm}$ & 1 \\
\hline$<3.0 \mathrm{~cm}$ & 5 \\
\hline \multicolumn{2}{|c|}{ f) Dysfunction score $(0-25$ points $)=A+B+C+D+E$} \\
\hline No impairment & 0 (index 0 ) \\
\hline Mild dysfunction & $1-4($ index 1$)$ \\
\hline Moderate dysfunction & 5-9 (index 2) \\
\hline Severe dysfunction & $10-13$ (index 3) \\
\hline Severe dysfunction & 15-17 (index 4) \\
\hline Severe dysfunction & 20-25 (index 5) \\
\hline
\end{tabular}

item "C" was assessed by bilateral palpation of the neck and jaw muscles, the item " $D$ " was analyzed in all movements cervical, presence or absence of pain in the execution of movements and the item " $E$ "was determined by the postural evaluation of the cervical spine through the postural assessment software (Project Portal Software for Postural Evaluation, São Paulo, Brazil). ${ }^{17}$

The test was completed, and the RT- 12 version was sent to the original author. After a favorable review of the author, the $\mathrm{T}-12$ version was approved for use in the final test (-Table 2 ).

The number of participants was determined according to Beaton et $\mathrm{al}^{15}{ }^{15}$ who describe in their study that the ideal sample should contain between 30 to 40 participants. 
Initially, the participants answered the question regarding the presence or absence of cervical pain. If their response was "yes", they classified the intensity of the pain from 0 to 10 according to the visual analog scale (VAS). Subsequently, all participants were assessed by a trained and qualified appraiser, who applied to them the Brazilian Portuguese version of the CDI.

The CDI is an index that evaluates neck mobility, muscle pain, pain during movement of the cervical spine, joint dysfunction, and posture.

Mobility was evaluated by the cervical mobility index, which was described by Wallace and Klineberg. ${ }^{13}$ During the analysis of the range of motion of the neck, the presence or absence of articular sounds is evaluated, for they may guide the evaluator regarding functional impairment: occasional snaps and clicks are probably related to muscle dysfunction, while cracks may be indicative of articular degeneration. ${ }^{13}$

Pain during movement is evaluated in flexion, extension, rotation and lateral inclination of the neck, and muscle pain is examined by palpation of the neck and jaw muscles.

The craniocervical posture was evaluated through a photographic record, with a biophotogrammetry analysis performed using the SAPO software, version 0.68 , which is a free software that provides linear and angular measurements. ${ }^{17}$

The software gives suggestions in its protocol regarding the marking points. Despite its set points, SAPO allows the evaluator to set their own point-marking protocol, so in this phase of the study, the adaptation of the marking has been made of dots and used the linear measurements, following the recommendations of the original instrument. ${ }^{17}$

Cervical lordosis was measured by horizontal distance, the greater the concavity of the cervical curvature, a vertical line that tangent the summit of thoracic kyphosis (-Fig. 1).

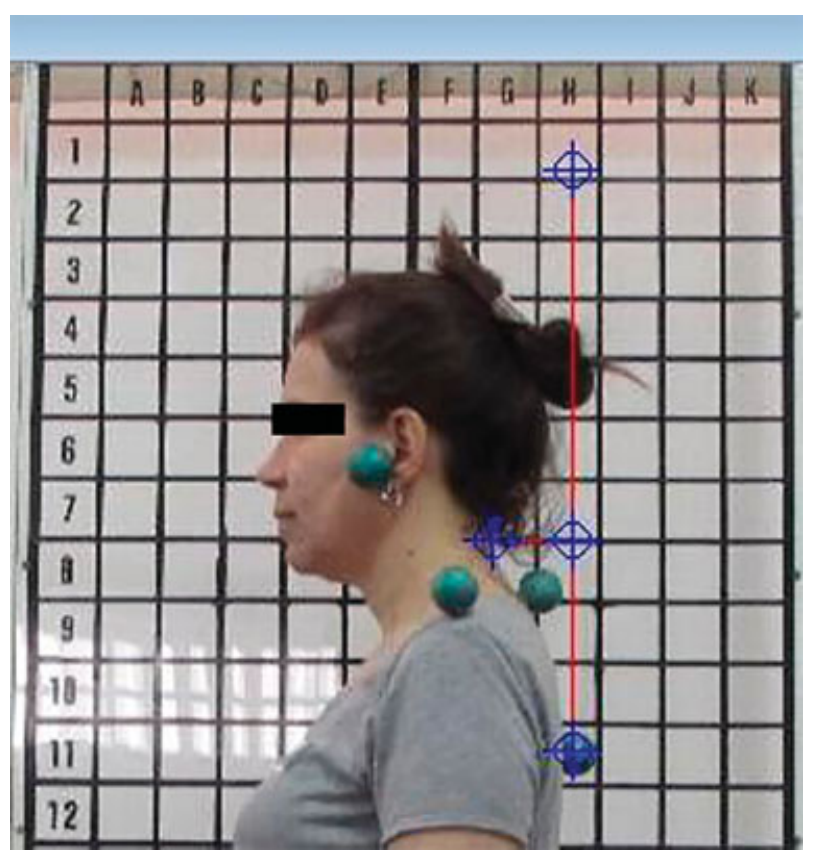

Fig. 1 Analysis of the distance of the craniocervical posture.
After collecting the data from $\mathrm{CDI}$, the correlation of the VAS with the Brazilian Portuguese version of the CDI was performed using Spearman correlation coefficient. The reliability and internal consistency were evaluated by Cronbach $\alpha$. For the validation, the Brazilian Portuguese version of the CDI was correlated with the VAS domains for cervicalgia and assessed by Spearman $\rho$. This coefficient varies from -1 to 1 : the closer it is to 1 or -1 , the stronger the association, the closer it is to zero, the weaker the relationship between the two variables.

\section{Results}

Certain terms received different or slightly different translations in the $\mathrm{T} 1$ and $\mathrm{T} 2$ versions; after an evaluation, a decision was made to maintain the terms used in the T1 version (-Table 1).

In the analysis of the back-translations, considering the idiomatic conceptual, cultural and semantic equivalence, and the word "movement" by "motion." After the back-translations, the phrase "impaired cervical joint function" "functional impairment in cervical joint," both have the same meaning being maintained at retranslated after analysis of the original author.

We observed no difficulty in the understanding and application of the Brazilian Portuguese version of the CDI, which did not require any changes in the formulation of the items. The mobility index, in the process of translation and back-translation, showed no discrepancies between the translators, remaining true to the original.

Among the participants who reported neck pain in the VAS, $84.21 \%$ suffered from craniocervical dysfunction according to the Brazilian Portuguese version of the CDI; as for those who reported neck pain in the VAS, $100 \%$ suffered from craniocervical dysfunction. The Brazilian Portuguese version of the CDI presented high reliability, as evidenced by Cronbach $\alpha,(0.717)$, which was 0.70 , the lowest recommended value. For the validation of the Brazilian Portuguese version of the CDI, Spearman correlation was used, and a strong correlation was found $(\rho=0.735 ; p=0.000)$ (-Fig. 2).

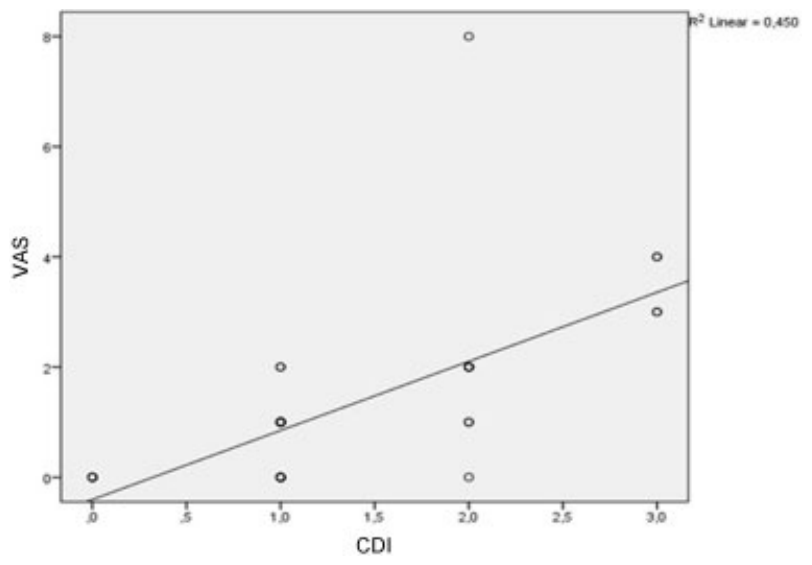

Fig. 2 Relationship between the VAS and CDI scores ( $r s=0.735$ $p=0.000 n=50)$. Abbrevations: CDI, craniocervical dysfunction index; VAS, visual analogue scale. 


\section{Discussion}

Neck pain is a musculoskeletal dysfunction that is very common among the general population. In the present study, teachers were evaluated because they tend to present more musculoskeletal dysfunctions than any other occupation. A high workload, along with the fact that they spend many hours in the standing posture and/or with their necks flexed due tasks such as reading, preparing lessons and tests, and correcting homework and tests are some of the causes of neck pain among teachers. $^{3-14}$

Cervical spine evaluations are often subjective, even when the index and questionnaires are used to assess the cervical pain, since most of these instruments rely on the selfreporting of the population.

Thus, providing a tool that takes into account all of the items used in the clinical evaluation, such as pain, range of motion, palpation and posture of the joint is important in order to choose the best treatment and to better monitor the patients.

The cultural adaptation of an assessment tool is of great importance, as a simple literal translation of the index does not encompass the cultural and social differences that may exist among different populations. ${ }^{18}$

The adaptation process of CDI underwent a rigorous methodology, with satisfactory results, given the objectivity and clarity of the instrument.

Since some of the items evaluated by the CDI form part of the postural assessment process used in Brazil, the cultural adaptation regarding expressions related to these items is necessary. Throughout the trial process, the evaluators had no difficulty understanding the items of the index.

The positive aspects of the instrument are the fact that its application is quick, simple, and the professionals who perform the postural assessment are already familiar with the evaluated items. Furthermore, the CDI is an instrument that detects functional changes even in asymptomatic individuals, and it can be used to prevent and treat craniocervical changes.

All of the translation and adaptation stages were performed simply and quickly, taking into account the most appropriate changes to Brazilian Portuguese. After the translations were reviewed and certain discrepancies were found, we chose to maintain the expressions used in T1, because they were more equivalent to the original $\mathrm{CDI}$ and the items evaluated in terms of semantics. The T1 version was made by a physiotherapist, and, because of this professional's familiarity with the functional and postural assessment process, T1 had expressions that were more technically accurate according to the original CDI.

During the trial phase, no difficulty regarding the understanding and application of the index was observed.

There are some studies in the Brazilian literature that have used the CDI in its original form. Bigaton et $\mathrm{al}^{19}$ evaluated the craniocervical posture in dysphonic women, and used the CDI to analyze the degree of severity of the craniocervical symptoms. A total of $37.5 \%$ of the sample had mild dysfunction, $37.5 \%$ had moderate dysfunction, and $25 \%$ had severe dysfunction. All of the control group (100\%) had mild dysfunction, and the researchers concluded that dysphonic women were clas- sified as having more pronounced craniocervical dysfunction clinically normal, suggesting the relationship of dysphonia with the changes of the cervical spine.

Weber et $\mathrm{al}^{7}$ verified the degree of craniocervical dysfunction severity in individuals with and without TMD. All of the sample $(100 \%)$ had some degree of cervical spine dysfunction; $48.65 \%$ of the control group was asymptomatic, while $88.24 \%$ of the TMD group presented symptoms.

These two studies corroborate the present study, since both of them showed that the CDI is an instrument useful in the early detection of disorders of the cervical spine.

In the Brazilian literature, most evaluations of disorders of the cervical spine are subjective, and the VAS is an instrument widely used to assess the severity of the symptoms. The present study shows that even though the CDI is a more complete instrument, it correlates with the VAS, but the VAS cannot detect dysfunction in asymptomatic individuals like the CDI.

\section{Conclusion}

After the translation, content adaptation and approval by the original author, the Brazilian version of CDI, which proved to be objective, easy to understand and a reliable tool to assess craniocervical dysfunction, came to be. The CDI showed a statistically significant correlation when compared with the VAS: the higher the VAS score, the higher the severity according to the CDI. In accordance with other previously performed studies, in the present study we observed that the CDI is also capable of detecting dysfunctions in asymptomatic individuals. The Brazilian version of the $\mathrm{CDI}$ is a valid and reliable instrument to evaluate the functional alteration of the craniocervical region.

\section{References}

1 Hoving JL, Pool JJ, van Mameren $\mathrm{H}$, et al. Reproducibility of cervical range of motion in patients with neck pain. BMC Musculoskelet Disord 2005;6(59):59

2 Defino PD, Rampim DB, Alfieri FM, et al. Cervicalgia: reabilitação. Acta Fisiátr 2012;19(02):73-81

3 Soares JC, Weber P, Trevisan ME, Trevisan CM, Rossi AG. Correlação entre postura da cabeça, intensidade da dor e índice de incapacidade cervical em mulheres com queixa de dor cervical. Fisioter Pesqui 2012;19(01):68-72

4 Reis FJJ, Mafra B, Mazza D, Marcato G, Ribeiro M, AbsalãoT. Avaliação dos distúrbios do controle sensório-motor em pessoas com dor cervical mecânica: uma revisão. Fisioter Mov 2010;23(04):617-626

5 Menoncin LCM, Jurkievicz AL, Silvério KCA, Camargo PM, Wolf NMN. Alterações musculares e esqueléticas cervicais em mulheres disfônicas. Arq Int Otorrinolaringol 2010;14(04):461-466

6 Bevilaqua-Grossi D, Chaves TC, de Oliveira AS. Cervical spine signs and symptoms: perpetuating rather than predisposing factors for temporomandibular disorders in women. J Appl Oral Sci 2007;15 (04):259-264

7 Weber P, Corrêa EC, Ferreira FdosS, Soares JC, Bolzan GdeP, Silva AM. Cervical spine dysfunction signs and symptoms in individuals with temporomandibular disorder. J Soc Bras Fonoaudiol 2012;24(02): 134-139

8 Corrêa ECR, Bérzin F. Temporomandibular disorder and dysfunctional breathing. Braz J Oral Sci 2004;3(10):498-502

9 Silverio KC, Siqueira LT, Lauris JR, Brasolotto AG. Muscleskeletal pain in dysphonic women. CoDAS 2014;26(05):374-381 
10 BenDebba M, Heller J, Ducker TB, Eisinger JM. Cervical spine outcomes questionnaire: its development and psychometric properties. Spine 2002;27(19):2116-2123, discussion 2124

11 Badaró FAR, Araújo RC, Behlau M. Escala funcional de incapacidade do pescoço de Copenhagen: tradução e adaptação cultural para o português brasileiro. J Hum Growth Dev 2014;24(03):304-312

12 Cunha SC, Nogueira RVB, Duarte AP, Vasconcelos BCE, Almeida RAC. Análise dos índices de Helkimo e craniomandibular para diagnóstico de desordens temporomandibulares em pacientes com artrite reumatoide. Rev Bras Otorrinolaringol 2007;73(01):19-26

13 Wallace C, Klineberg IJ. Management of craniomandibular disorders. Part 1: A craniocervical dysfunction index. J Orofac Pain 1993;7(01):83-88

14 Erick PN, Smith DR. A systematic review of musculoskeletal disorders among school teachers. BMC Musculoskelet Disord 2011;12:260-271
15 Beaton DE, Bombardier C, Guillemin F, Ferraz MB. Guidelines for the process of cross-cultural adaptation of self-report measures. Spine 2000;23:83-91

16 Ferreira EAG. Postura e controle postural: desenvolvimento e aplicação de método quantitativo de avaliação postural [thesis]. São Paulo: University of São Paulo; 2005:114

17 Sanchez HM, Gusatti N, Sanchez EGM, Barbosa MA. Incidência de dor musculoesquelética em docentes do ensino superior. Ver Bras Med Trab 2013;11(02):66-75

18 Paula Erika Alves F, Cunha F, Onishi ET, Branco-Barreiro FC, Ganança FF. Tinnitus handicap inventory: cross-cultural adaptation to Brazilian Portuguese. Pro Fono 2005;17(03):303-310

19 Bigaton DR, Silvério KCA, Berni KCS, Distefano G, Forti F, Guirro RRJ. Postura cranio cervical em mulheres disfonicas. Rev Soc Bras Fonoaudiol 2010;15(03):329-334

Appendix Brazilian version in Portuguese of the craniocervical dysfunction index

\begin{tabular}{|c|c|}
\hline Critério & Escala \\
\hline \multicolumn{2}{|l|}{ A) Comprometimento da Amplitude de movimento / Índice de mobilidade } \\
\hline Amplitude de movimento normal & 0 \\
\hline Amplitude de movimento levemente prejudicada & 1 \\
\hline Amplitude de movimento severamente prejudicada & 5 \\
\hline \multicolumn{2}{|l|}{ B) Comprometimento funcional na articulação cervical } \\
\hline Movimento suave, sem sons ou dor na articulação cervical & 0 \\
\hline $\begin{array}{l}\text { Sons na articulação cervical - click, estalido ou ruído } \\
\text { com o movimento da cabeça }\end{array}$ & 1 \\
\hline Bloqueio - cabeça ou pescoço, momentaneamente fixo & 5 \\
\hline \multicolumn{2}{|l|}{ C) Dor muscular } \\
\hline Ausência de sensibilidade à dor na palpação nos músculos cervicais & 0 \\
\hline Sensibilidade à dor na palpação de 1 a 3 locais palpados & 1 \\
\hline Sensibilidade à dor na palpação em 4 ou mais locais palpados & 5 \\
\hline \multicolumn{2}{|l|}{ D) Dor no movimento cervical } \\
\hline Nenhuma dor ao movimento & 0 \\
\hline Dor durante um movimento & 1 \\
\hline Dor em dois ou mais movimentos & 5 \\
\hline \multicolumn{2}{|l|}{ E) Postura craniocervical } \\
\hline$>6 \pm 0,5 \mathrm{~cm}$ & 0 \\
\hline $4.5 \pm 0,5 \mathrm{~cm}$ & 1 \\
\hline$<3,0 \mathrm{~cm}$ & 5 \\
\hline \multicolumn{2}{|l|}{ F) Escore de Disfunção (0-25 pontos) $=\mathrm{A}+\mathrm{B}+\mathrm{C}+\mathrm{D}+\mathrm{E}$} \\
\hline Sem Disfunção & 0 (índice 0 ) \\
\hline Disfunção leve & 1-4 (índice 1) \\
\hline Disfunção moderada & 5-9 (índice 2) \\
\hline Disfunção severa & 10-13 (índice 3) \\
\hline Disfunção severa & 15-17 (índice 4) \\
\hline Disfunção severa & 20-25 (índice 5) \\
\hline
\end{tabular}

